\title{
Hotel entrepreneurship in a turbulent environment
}

This article was published in the Journal International Journal of Hospitality Management

(2016) vol. 53, 1-11 DOI: URL: http://dx.doi.org/10.1016/j.ijhm.2015.11.008

Authors' Details:

Vlatka Skokic

School of Hospitality and Tourism Management, University of Surrey, Guildford GU2 7XH, UK

Email: v.skokic@surrey.ac.uk

Phone: 0044 (0) 7809766384

Paul Lynch

Edinburgh Napier University, Business School, 219 Colinton Road, Edinburgh EH14 1DJ, UK

Email: p.lynch@napier.ac.uk

Phone: +44 01314554621

Alison Morrison

Hamlet Hill Consultancy, 12 Hamlet Hill, Cove G84 0NB, Scotland, UK

Email: alison@hamlethill.co.uk

Phone: +4407467 948089. 


\title{
Hotel entrepreneurship in a turbulent environment
}

\begin{abstract}
This paper aims to explore the factors that stimulate entrepreneurship among small hotels in a former socialist economy which experienced a turbulent economic and social transition period. The study investigates how specific aspects such as a low level of competition and position of the entrepreneurs in society, acted as facilitating or inhibiting factors for entrepreneurship. The findings from in-depth interviews with 37 hotel entrepreneurs demonstrate that institutional deficiencies influence market orientation of the entrepreneurs and that the specific social context sets the conditions by which lifestyle-related motives will exist or not. They also underscore that investigation of entrepreneurs needs to take account of a broad range of sociocultural factors and not solely entrepreneurial agency. Inclusion of a transitional economic and social setting into the broader theoretical framework of hospitality entrepreneurial research demonstrates the value of a contextualized approach.
\end{abstract}

Keywords: Hotel entrepreneurs; Lifestyle orientation, Transition economies, Croatia

\section{Introduction}

In the last three decades, there has been increased interest in entrepreneurship and small hospitality and tourism firms (SHTF). Much of the literature is concerned with developed economies and has investigated the motivation and characteristics of small firms' ownermanagers. It is argued that the vast majority of these individuals are lifestyle-oriented and do not seek to grow their businesses (Ateljevic and Doorne, 2000; Ateljevic, 2007; Getz and Petersen, 2005; Shaw and Williams, 2004). Consequently, they are described as 'lifestyle entrepreneurs' (Williams et al. 1989), 'non entrepreneurs' (Shaw and Williams, 1998) and even as 'laggards' (Ioannides and Petersen, 2003).

Although such studies have made a significant contribution towards our knowledge of SHTF, they only partially explain factors that stimulate entrepreneurship. A majority of the studies investigating start-up motives of entrepreneurs somehow ignore the socio-cultural environment where entrepreneurs operate. In the most recent analysis of the field, Thomas et al. (2011, p. 966) demonstrate that 'almost exclusive attention is given to agency (usually business motivation) with little consideration of significant mediating factors such as gender, ethnicity and wider socio-economic conditions.' This gap in the literature is somewhat surprising given that there is a growing recognition that entrepreneurship 'can be better understood within its historical, temporal, institutional, spatial, and social contexts' (Welter, 2011, p. 165). From this perspective, the socio-economic context where entrepreneurs are embedded is seen as a key factor which has an impact on the extent of entrepreneurship as well as the way entrepreneurs behave (Welter and Smallbone, 2011).

The aim of the present study is to address this gap and to investigate the socio-economic determinants of entrepreneurial activity among small hotels in the Republic of Croatia, which is a former socialist economy and represents a case study of SHTF in the economies of Central and Eastern Europe (CEE). It can be argued that the adopted perspective is of significant importance for researching entrepreneurship in transitional settings, as the institutional shift from socialism to capitalism offers a 'laboratory setting' to examine entrepreneurship in a turbulent environment that is characterized by complex political and economic changes' (Ireland et al. 2008, p. 124). Another reason for this perspective is that a number of studies found that social context can both foster and inhibit entrepreneurial endeavors and activities (Dickson and Weaver, 2008). The paper draws on two key ideas from the literature on SHTF 
and entrepreneurship in transition economies: the issue of entrepreneurial motivation to start a small firm, and the socio-economic environment for entrepreneurship.

A major implication of our research is that it underlines that the socio-economic context can act positively on entrepreneurship even when it is expected to constrain it. We were able to arrive at this observation by going beyond the boundaries of micro-level presumptions and in this way, our study speaks to Thomas et al.'s (2011) call to focus more on mediating factors that influence hospitality and tourism entrepreneurs. Our study also demonstrates the value of a contextualized approach in entrepreneurship research (Welter, 2011). By understanding the nature, richness and diversity of the entrepreneurial phenomenon, researchers can offer more insightful and theoretically grounded explanations of entrepreneurship.

\section{Theoretical background}

\subsection{Contextualized entrepreneurship research}

Generic entrepreneurship research has undergone a shift in focus in the last twenty years, from individual entrepreneur to the role of the institutional environment on entrepreneurial activity (Veciana and Urbano, 2008). The rejection of the dominant 'psychological approach' has led entrepreneurship scholars to consider the institutional approach to entrepreneurship, as a much more promising approach to explain the complexities of the phenomena (Shane, 2003). The institutional perspective draws on the concept of formal and informal institutions introduced by North (1990) and the consequent studies have investigated a range of issues, such as, the impact of formal institutions on entrepreneurship, such as laws and regulations for market entry (Smallbone and Welter, 2001) or availability of finance (Aidis et al. 2008) and the impact of informal institutions on entrepreneurial activity, such as the impact of cultures (Hayton et al. 2002)

For instance, today it is widely acknowledged that too many rules and procedural requirements, or a lack of funding will not only negatively reflect on entrepreneurship rates but will also impede the trajectories of entrepreneurial ventures (Veciana and Urbano, 2008). In addition, numerous studies show that an insecure institutional framework is even more inhibiting to entrepreneurship than financial barriers (Johnson et al. 2002; Pissarides, 1998). For instance, Johnson et al. (2002) analyzed small manufacturing firms in five transition economies and found that entrepreneurs will reinvest less of their retained profit when they perceive insecure property rights, despite having their own money or suitable collateral. Harbi and Anderson's (2010) study further demonstrated that institutional conditions are also related to the form of entrepreneurship that emerges. For instance, their findings suggest that corruption promotes self-employment (as necessity entrepreneurship) but discourages innovation (as opportunity entrepreneurship). Investigating the effects of culture on entrepreneurial activity, Davidsson and Wiklund (1997) proposed that cultures that promote a higher need for achievement and autonomy, as well as self-efficacy, will have higher firm-formation rates.

Despite the fact that institutional theory has proven highly useful in entrepreneurship research, it is still exclusively focused on the formal or informal constraints, whilst ignoring other factors that affect entrepreneurship (Bruton et al. 2010; Veciana and Urbano, 2008; Welter, 2011). This has led scholars to acknowledge the value of contextualized entrepreneurship research (Welter, 2011), which implies that a specific venture is embedded spatially, institutionally, and temporally. This position implies that entrepreneurship theory needs to be contextualized as well by 'paying attention to situational and temporal boundaries for entrepreneurship, in order to frame adequately research questions and designs' (p. 177). In order to bring this perspective to the H\&T entrepreneurship studies, this study contextualised itself spatially (Croatia, small hotel firms), institutionally (regulatory environment, country 
history and the position of entrepreneurship) and temporally (economic restructuring, transition). A contextualized theory perspective implies that the study also integrates the theoretical "context lens" that have dominated research so far. Thus, issues around small firms in H\&T and transition economies are discussed to enhance the contextualised dimension.

\title{
2.2. Small firms in hospitality and tourism
}

Since Shaw and Williams (1987) and Williams et al. (1989) observed the characteristic of SHTF, arguing that they represent forms of consumption as much as production, many subsequent studies (Table 1) have confirmed the prioritization of consciously selected lifestyle motives in running those businesses. Most studies, conducted mainly in developed economies, argue that SHTF can be generically described as lifestyle enterprises. According to Morrison et al. (2001, p. 17) lifestyle entrepreneurs are those who are likely to be concerned with:

\begin{abstract}
survival and securing sufficient income to ensure that the business provides them and their family with a satisfactory level of funds to sustain enjoyment in their chosen lifestyle...[The] lifestyle proprietor defines an individual who has a multiple set of goals associated with their businesses. Profitability in their business operations will be only one of these goals.
\end{abstract}

Thomas (2004) argues that the behavior of this type of entrepreneur very often does not fit with traditional models of business activity and profit-oriented goals. These entrepreneurs have multiple goals, but they are mostly personal and non-economic, such as to 'be my own boss' (Chen and Elston, 2013); to do interesting work (Page et al. 1999); to enjoy a good lifestyle (Hall and Rusher, 2004); and to live in a certain area (Getz and Carlsen, 2000). Andersson et al.'s (2002, p. 101) results demonstrate that 'even when the owners set out explicitly to make money, their underlying preferences were to move to or remain in the country or in small towns and resorts.' 
Table 1

An overview of the literature review.

\begin{tabular}{|c|c|c|c|c|}
\hline \multirow[b]{2}{*}{ Authors } & \multicolumn{4}{|c|}{ Characteristics } \\
\hline & Aim & Methodology & Setting & Participants \\
\hline $\begin{array}{l}\text { Ahmad et al. } \\
\text { (2014) }\end{array}$ & $\begin{array}{l}\text { To analyze the start-up } \\
\text { motivation factors and } \\
\text { business challenges }\end{array}$ & $\begin{array}{l}\text { Multi-method } \\
\text { (questionnaire } \\
\text { and interviews) }\end{array}$ & Malaysia & $\begin{array}{l}\text { Home-stay } \\
\text { accommodation } \\
\text { businesses }\end{array}$ \\
\hline Ahmad (2015) & $\begin{array}{l}\text { To investigate the } \\
\text { determinants and } \\
\text { characteristics of the } \\
\text { owners/managers of SMS } \\
\text { hotels }\end{array}$ & $\begin{array}{l}\text { Multi-method } \\
\text { (questionnaire } \\
\text { and semi- } \\
\text { structured face to } \\
\text { face interviews) }\end{array}$ & $\begin{array}{l}\text { United Arab } \\
\text { Emirates } \\
\text { (Dubai, Abu } \\
\text { Dhabi and } \\
\text { Fujairah) }\end{array}$ & SMS Hotels \\
\hline $\begin{array}{l}\text { Andersson et } \\
\text { al. (2002) }\end{array}$ & $\begin{array}{l}\text { To investigate the goals of } \\
\text { family businesses } \\
\text { in the rural tourism and } \\
\text { hospitality sector }\end{array}$ & $\begin{array}{l}\text { Cross-case } \\
\text { comparison (9 } \\
\text { cases) }\end{array}$ & $\begin{array}{l}\text { Sweden, } \\
\text { Canada and } \\
\text { Australia }\end{array}$ & $\begin{array}{l}\text { STH family } \\
\text { firms in rural } \\
\text { areas or small } \\
\text { cities }\end{array}$ \\
\hline $\begin{array}{l}\text { Andriotis } \\
(2002)\end{array}$ & $\begin{array}{l}\text { Influence of small local } \\
\text { firms on economic } \\
\text { development }\end{array}$ & Questionnaire & $\begin{array}{l}\text { Greece } \\
\text { (island of } \\
\text { Crete) }\end{array}$ & $\begin{array}{l}\text { Owner- } \\
\text { managers of } \\
\text { accommodation } \\
\text { units }\end{array}$ \\
\hline $\begin{array}{l}\text { Ateljevic } \\
(2007)\end{array}$ & $\begin{array}{l}\text { To identify issues that } \\
\text { affect management } \\
\text { practice of SHTF }\end{array}$ & $\begin{array}{l}\text { Multi-method } \\
\text { (questionnaire } \\
\text { and in depth } \\
\text { interviews) }\end{array}$ & $\begin{array}{l}\text { New Zealand } \\
\text { (four regions) }\end{array}$ & SHTF \\
\hline $\begin{array}{l}\text { Ateljevic } \\
(2009)\end{array}$ & $\begin{array}{l}\text { To examine the } \\
\text { entrepreneurial behavior } \\
\text { of SHTF and their ability } \\
\text { to contribute to regional } \\
\text { development }\end{array}$ & $\begin{array}{l}\text { Multi-method } \\
\text { (In-depth } \\
\text { interviews and a } \\
\text { questionnaire) }\end{array}$ & $\begin{array}{l}\text { New Zealand } \\
\text { (Wairarapa) }\end{array}$ & $\begin{array}{l}\text { SHTF; public } \\
\text { and private } \\
\text { sector } \\
\text { organizations } \\
\text { and agencies }\end{array}$ \\
\hline $\begin{array}{l}\text { Ateljevic and } \\
\text { Doorne (2000) }\end{array}$ & $\begin{array}{l}\text { The value position and } \\
\text { motivating values of } \\
\text { small-scale lifestyle } \\
\text { entrepreneurs }\end{array}$ & $\begin{array}{l}\text { Qualitative (in- } \\
\text { depth interviews; } \\
\text { ethnographic } \\
\text { fieldwork over } 7 \\
\text { years }\end{array}$ & $\begin{array}{l}\text { Across New } \\
\text { Zealand }\end{array}$ & $\begin{array}{l}\text { SHTF (owners, } \\
\text { managers and } \\
\text { employees) }\end{array}$ \\
\hline $\begin{array}{l}\text { Ateljevic and } \\
\text { Doorne (2003) }\end{array}$ & $\begin{array}{l}\text { To identify and } \\
\text { understand cultural } \\
\text { complexities around } \\
\text { tourism entrepreneurs }\end{array}$ & $\begin{array}{l}\text { Multi-method } \\
\text { (in depth } \\
\text { interviews, } \\
\text { observation and } \\
\text { questionnaire) }\end{array}$ & $\begin{array}{l}\text { Croatia } \\
\text { (Murter } \\
\text { village) }\end{array}$ & SHTF \\
\hline $\begin{array}{l}\text { Banki and } \\
\text { Ismail (2015) }\end{array}$ & $\begin{array}{l}\text { To investigate he } \\
\text { characteristics of family } \\
\text { owned tourism micro } \\
\text { businesses in mountain } \\
\text { destinations in developing } \\
\text { countries }\end{array}$ & $\begin{array}{l}\text { Semi-structured } \\
\text { face-to-face in- } \\
\text { depth } \\
\text { interviewing }\end{array}$ & $\begin{array}{l}\text { Nigeria } \\
\text { (Obudu } \\
\text { Mountain } \\
\text { region) }\end{array}$ & $\begin{array}{l}\text { Family owned } \\
\text { SHTF in rural } \\
\text { areas }\end{array}$ \\
\hline $\begin{array}{l}\text { Chen and } \\
\text { Elston (2013) }\end{array}$ & $\begin{array}{l}\text { To investigate } \\
\text { characteristics of small } \\
\text { restaurant owners in } \\
\text { China }\end{array}$ & Questionnaire & $\begin{array}{l}\text { China (four } \\
\text { cities) }\end{array}$ & $\begin{array}{l}\text { Small } \\
\text { restaurants }\end{array}$ \\
\hline $\begin{array}{l}\text { Gartner } \\
(2004)\end{array}$ & $\begin{array}{l}\text { To examine factors } \\
\text { affecting SHTF }\end{array}$ & Questionnaire & $\begin{array}{l}\text { Africa } \\
\text { (central }\end{array}$ & $\begin{array}{l}\text { Small hotels and } \\
\text { restaurants }\end{array}$ \\
\hline
\end{tabular}


Glancey and Pettigrew (1997)

Hall and

Rusher (2004)

Hallak et al.

(2012)

Ioadinnes and
Petersen
$(2003)$

Jaafar et al.

(2011)

Komppula

(2004)

Lashley and
Rowson
(2009)
Morrison and
Teixeira
(2004)

Mottiar (2007)

$\begin{array}{ll}\text { Mottiar (2007) } & \text { To examine the } \\ & \text { between firms and within } \\ \text { the location }\end{array}$

Page et al. (1999)

Ramos-

Rodríguez et al. (2012)

To examine the nature of entrepreneurial activity in the small hotel sector

To investigate the profile of $\mathrm{B} \& \mathrm{~B}$ operations and their attitude about the risk and lifestyle

To examine how place identity, entrepreneurial self-efficacy, and support for community influence the performance of SHTF To investigate the key characteristics and innovation levels among the SHTE

\section{To examine the} characteristics of small and medium hotel owners/managers and the issues and problems they confront in relation to their survivability in the industry

To examine the growth motivations and definitions of success among rural tourism entrepreneurs

To understand characteristics and motivational factors of small hotel owners

To investigate the characteristic of SHTF and their effects on performance the location

To examine different characteristics of SHTF and their role in tourism (island of
Structured interviews

In-depth interviews

Questionnaire (through telephone interviews)

Semi- structured in- depth interviews

Semi-structured questionnaire through in-depth interviews

Questionnaire

\section{UK}

(Blackpool) owners

Small hotel

Bornholm)

Owners and

New Zealand B\&B

(North

Island)

$\begin{array}{ll}\text { Confirmatory } & \text { South } \\ \text { factor analysis } & \text { Australia }\end{array}$

SHTF

East

Peninsular

Malaysia

\section{Eastern}

Finland

\section{Rural H\&T}

enterprises

SHTE

Small hotels

Region of

Scotland (St Small hotels

Andrews)

Scotland Accommodation

(Glasgow) units

Ireland
(Westport)

Lifestyle owners and local tourism representatives

New Zealand SHTF (Northland)

Logistic regression (GEM data)

43 countries

Small hotels and participating restaurants
likelihood of being a
hotel and restaurant
entrepreneur

certain factors on the 


\begin{tabular}{|c|c|c|c|c|}
\hline $\begin{array}{l}\text { Saprunova } \\
(2004)\end{array}$ & $\begin{array}{l}\text { To investigate factors } \\
\text { which stimulate } \\
\text { development of SHTF, } \\
\text { key problems in their } \\
\text { development and support } \\
\text { measures. }\end{array}$ & $\begin{array}{l}\text { Observation and } \\
\text { insights over } 10 \\
\text { years }\end{array}$ & Russia & SHTF \\
\hline $\begin{array}{l}\text { Shaw and } \\
\text { Williams } \\
\text { (1987) }\end{array}$ & $\begin{array}{l}\text { To investigate the } \\
\text { formation and the } \\
\text { operating features }\end{array}$ & Questionnaire & $\begin{array}{l}\text { England } \\
\text { (Looe, south- } \\
\text { east } \\
\text { Cornwall) }\end{array}$ & SHTF \\
\hline $\begin{array}{l}\text { Zapalska and } \\
\text { Brozik (2007) }\end{array}$ & $\begin{array}{l}\text { To examine the nature of } \\
\text { SHTF and to analyze the } \\
\text { business environment }\end{array}$ & Telephone survey & $\begin{array}{l}\text { Poland (6 } \\
\text { southern } \\
\text { regions) }\end{array}$ & SHTF \\
\hline $\begin{array}{l}\text { Zhao and Getz } \\
\text { (2008) }\end{array}$ & $\begin{array}{l}\text { To investigate and } \\
\text { understand the } \\
\text { characteristics and goals } \\
\text { of rural family business } \\
\text { owners }\end{array}$ & Questionnaire & $\begin{array}{l}\text { China } \\
\text { (Guangxi } \\
\text { Zhuang) }\end{array}$ & SHTF \\
\hline
\end{tabular}

Despite a significant growth in the number of studies investigating SHTF (Table 1), those studies have three limitations: i) knowledge on the subject is mainly drawn from the perspective of western developed economies, with a paucity of studies focusing on transition and developing countries; ii) almost exclusive attention is given on business motivation, with limited consideration of mediating factors such as entrepreneurs' socio-economic environment; and iii) reliance on quantitative methods (see also Thomas et al. 2011) has been useful in highlighting distinguishing characteristics of small firms and their owners, but is limited in explaining in detail the range of social, economic, cultural and political issues affecting them. Although Shaw and Williams (1998) observed more than a decade ago that many entrepreneurs become embedded in their communities, Ateljevic and Doorne (2003, p.127) argue that 'the socio-cultural barriers and local contingencies shaping entrepreneurship have been traditionally overlooked in the process.' In recent years, an increasing number of scholars have aimed to include in-depth cultural analysis of entrepreneurs, such as Ateljevic and Doorne (2003) and Tucker (2010). These studies reveal the limitations of the overtly individualistic approach but they do not explicitly analyze how different mediating factors shape motivations and behaviors of hospitality and tourism entrepreneurs.

Analysis of available case studies originating from the CEE and from developing economies (see Table 1) further justifies the calls to contextualize entrepreneurship research. First, such studies reveal a mix of both economic and non-economic entry motives which exist simultaneously. Particularly interesting dimensions are autonomy and independence, which are seen as purely non-economic motives, in contrast to Western literature where these are expressed as both lifestyle and economic factors (Getz and Petersen, 2005). Second, a majority of these studies tend to focus on a number of specific issues affecting the SHTF such as shortage of capital, bureaucracy and high levels of bribery and corruption. However, accounts that explain how these issues connect to entrepreneurial behavior have not been provided. Thus, there is a need to expand the investigation of hospitality and tourism entrepreneurs to include a much broader range of socio-cultural factors and to explore how entrepreneurs navigate the socio-cultural environment.

\subsection{Development of entrepreneurship in former socialist economies}

Although the communist system was not identical among the CEE countries, it can be argued that the one-party system and anti-entrepreneurial norms and beliefs were a distinctive 
feature of former socialist economies (Ireland, et al. 2008). Two particular features of the communist period did not leave any scope for development of entrepreneurship. Firstly, the Communist Party eliminated one of the major institutions of capitalism: private ownership and the right to establish private enterprises (Aidis, 2005). In some countries, such as Poland, Hungary and the former Yugoslavia, the sector of small firms did exist but those firms were restricted to certain economic sectors, such as agriculture and tourism (Chilosi, 2001). However, politically determined limits were imposed on the size of firms, such as the number of employees (Kolodko, 2000). Secondly, it can be argued that anti-entrepreneurial norms and beliefs were even more inhibiting to entrepreneurship. Entrepreneurs were seen and ideologically portrayed as exploiters, deviant individuals, a Western threat and enemies of the people (Kovac, 1990; Manolova et al. 2008). Besides similarities in the socialist system, all former socialist countries shared the transition process, where the privatization process was the core of post-socialist transition (Aidis, 2005). It was assumed that the de-nationalisation of state assets would bring fast growth of microeconomic efficiency (Kolodko, 2000). However, the privatization process did not achieve the expected restructuring and in fact hindered the development of entrepreneurial activities (Williams and Baláž, 2002).

The institutional framework has played an important role in entrepreneurship development (Aidis et al. 2008). Although the institutional reforms made entrepreneurial endeavors possible after decades of suppression of private initiative, the very same reforms created institutional chaos which constrained the emergence of entrepreneurship (Estrin et al. 2006). In most of the CEE countries, the institutional environment has been described as immature and underdeveloped, where a lack of property rights enforcement, administrative barriers and high rates of corruption did not provide support for entrepreneurial ventures (Aidis et al. 2008). Bureaucratic restrictions when starting up a business created additional barriers to entry and hampered the impact of the legal process of liberalization in releasing the entrepreneurial capabilities. Increased rates of corruption and unofficial activity have contributed to negative attitudes toward entrepreneurship. Chilosi (2001, p. 341) argues that 'entrepreneurship is tainted as 'speculation' and entrepreneurs may be seen as exploiters.'

At the same time, previous studies have suggested that changes in political forces, regulation, and macroeconomic influences can be critical factors for the emergence of new opportunities (Scase, 2000). This appears particularly applicable in the case of CEE transitional economies, where the business environment has undergone significant changes from a socialist to a market system. Nevertheless, this transition between systems and attendant opportunities that have emerged has received little attention from scholars. A study by Smallbone et al. (2010) is a rare example. Addressing development of small firms in the business service sector in Ukraine, their findings show how 'entrepreneurs try to fill gaps left by the new regulations and rules, or offer assistance in circumventing bureaucratic regulations' (p. 658). Additionally, these firms grew by identifying new opportunities resulting from inefficient institutional structures.

\section{The study context: Croatia}

Croatia was a part of former Yugoslavia from 1945 until 1991. Yugoslavia used to be a federal and socialist republic consisting of six federal units and two provinces. Entrepreneurship was viewed as a phenomenon coming from a capitalist ideology and aiming to achieve material gains through the exploitation of others (Kovac, 1990). Tourism was one of the rare industries where private initiative was developing. In 1974, the Yugoslav government enabled the establishment of private enterprises in agriculture and tourism. However, the government was reluctant to legalize private property. A maximum of five employees could be employed, but only in exceptional circumstances (Kobasic, 1987). Entrepreneurial movement was prevalent 
within the accommodation sector where a vast number of people started to rent summer houses illegally (Ateljevic and Doorne, 2003).

Tourism activity was growing rapidly in Croatia until the civil war in the 1990s, when Croatia declared independence and broke away from the socialist tradition. Within the former Yugoslavia, Croatia was the most popular tourist destination with a share of more than $75 \%$ of the total tourist arrivals. These reached a peak of 10.3 million in 1989 . More than $75 \%$ of the total accommodation capacities of Yugoslavia were based in the coastal part of Croatia (Kobasic, 1987). The accommodation sector has been structured around large publicly owned hotels and family-run home stay rentals, usually called private apartments. As in the majority of other CEE economies such a vast legacy of fixed capital in the accommodation sector became 'the object of a contest over property rights in the course of privatization' (Williams and Baláž, 2002, p. 38).

The new Croatian government established that Croatia needed to have two hundred rich families/entrepreneurs to form the cornerstone of the new Croatian market economy (Sekulic and Sporer, 2000). The government through the privatization policy enabled those privileged individuals to buy state owned companies - where a significant proportion were large hotel firms - far below their market price. Those entrepreneurs were obliged to invest money and to adapt those companies to the new market challenges. However, in reality the practice was to buy enterprises and strip their assets. This inappropriate privatization policy, combined with the systematic stifling of private enterprise, served to suffocate the entrepreneurial spirit significantly. Consequently, people perceived entrepreneurs as privileged criminals, as tycoons connected with corruption (Kovac, 1990).

After the end of the civil war in 1995, tourism revenues and tourist arrivals steadily increased. The tourism industry represents the most important industry for the Croatian economy, contributing more than 27\% to the GDP in 2013 (WTTC, 2014). However, this growth in tourism has occurred in the context of slow overall institutional development. The latest report on perception of entrepreneurship across Europe (Eurofound, 2015) reports on a prevailing negative attitude toward entrepreneurs in Croatia, where almost $70 \%$ of the Croatian participants agree with the statements that 'entrepreneurs exploit the work of other people'.

\section{Methods}

\subsection{Sampling}

The sample for this study consists of the owners of small and medium sized (SMS) hotels in Splitsko-dalmatinska county in Croatia. Participants were selected purposively, as is usually the case in qualitative research (Miles and Huberman, 1994). Two key factors suggested the sample. First, Croatia has poorly developed statistical databases and the exact number of SHTF is not available. The National Hotel Classification, updated on a biannual basis, provides a relatively up-to-date business record of hotels with their size capacity and the source of ownership. It hence provides a rare systematic sampling framework to study entrepreneurship in a transition economy. Second, the level of tourism development differs considerably within individual regions in Croatia. Therefore, the Splitsko-dalmatiska county was selected as the most suitable for this research because it has a long established tourist tradition and in recent years entrepreneurial activity within the industry has grown rapidly.

Through the National Hotel Classification it was possible to identify hotels in the study area, together with their size capacity and source of ownership. For the purposes of sampling, a SMS hotel is one that does not have more than 40 letting rooms, as defined by The Croatian Ministry of Tourism (MINT, 2005). Out of a population of 114 hotels in the analysed county, 64 SMS hotels were identified. Access to entrepreneurs is not an easy task and, in most cases, 
some kind of introduction to entrepreneurs is necessary. Two letters were sent together to the entrepreneurs. The first explained the purpose of the study and invited their participation. The second letter, written and signed by experts such as university professors and officials from the various national bodies, such as Ministries and Chambers of Commerce, emphasized the study's importance.

A pre-study was conducted among four hotel entrepreneurs whose purpose was: to trial the semi-structured interview as a main method of data collection using an interview guide; to test the initial assumption that potential participants have to be contacted by phone rather than email; to assess the degree of cooperation; and to test identified theoretical themes (entry motivation, institutional support for entrepreneurship, position of entrepreneurs in the society and economic conditions). It was found that participants were best contacted via telephone and a flexible interview guide was preferred by the participants.

Out of the remaining 60 small hotels identified, 33 hotel owners were interviewed thus 37 in total. The research continued until theoretical saturation was reached (Eisenhardt, 1989). Interviews were conducted in urban areas (city center and seaside - 26), islands (seven) and inland parts of the county (four). Most interviews were conducted in the hotels.

\subsection{Data analysis}

All interviews were conducted in the Croatian language. The interviews with the hotel entrepreneurs were tape recorded and fully transcribed. The average interview length was one and a half hours, resulting in more than 750 pages of written transcripts. In order to ensure transcription quality and accuracy, the interview transcription and coding were conducted in the Croatian language (Paz, 1992). Becoming completely familiar with the text, meanings and interpretations within it, it was possible to translate all the interviews in English. Interviews are referred to by the labels $\mathrm{H} 1$ through $\mathrm{H} 37$ with each number representing one entrepreneur.

The data analysis is qualitative, based on inductive approach and framework analysis. It consists of six key stages, identified by Ritchie and Spencer (1994) as: familiarization; identifying a thematic framework; indexing; charting; and mapping and interpretation. Familiarization started by iteratively reviewing the data, which involved multiple listening to the audiotapes and readings of the transcribed text and making reflective remarks. Familiarization with the data enabled the development of in-vivo codes or 'emergent issues' (Flick, 2009) which attempt to use participants' own terms in order to capture a key element of what is being described. For instance, one of the in-vivo codes was 'marginalized voices' (originally labeled as position of entrepreneurs in the society). At this stage, a first draft of the thematic framework was developed.

The emerging thematic framework was constantly compared to theoretical conceptualizations, working back and forth between various categorizations of the data. For instance, one of the investigated themes was 'entry motivations'. After applying the emergent thematic framework to the first few interviews it became clear that the 'entry motivation' has to be analyzed together with the 'life history' and 'future goals' to truly capture the individual circumstances which have triggered study participants into entrepreneurship. First-order coding was then followed by a subsequent round of second-order coding. For instance, during the round of first-order coding, descriptive codes were developed which attempted to describe various background information provided by the participants, such as: previous H\&T experience, previous experience of running a small firm, effects of war and transition and returning migrants. During the second-order coding, these descriptive codes were grouped into an analytical code or a master code 'life history'. Similarly, descriptive codes (tycoons, mistrust, reputation, privatization policy, thieves, criminals) were used to tease out participants feelings of being an entrepreneur. These descriptive codes were grouped as 'marginalized voices'. After 
numerous iterations, and rounds of second order coding, 7 master codes were teased out (lack of institutional support, marginalized voices, life history, entry motivations, future goals, low competition and high growth potential).

In the next stage of analysis it was important to group coded text segments according to assigned code categories and to compile data charts for each theme across all cases, which enabled the reduction of the amount of material to a more manageable level. An example of a such matrix is provided in Table 2 .

Table 2

Matrix Exemplar: Entry Motivation.

\begin{tabular}{|c|c|}
\hline \multirow[b]{2}{*}{ PARTICIPANT } & Thematic code EM: SO (Entry motives/Spotted Opportunity) \\
\hline & Coded text segment, meaning interpretation and transcript reference \\
\hline H1 & $\begin{array}{l}\text { - Portfolio entrepreneur } \\
\text { - Entry seen as an opportunity, emphasis on the entrepreneur's } \\
\text { judgment, vision (86-99) } \\
\text { - A clear decision, willing to take the risk (275-277) }\end{array}$ \\
\hline $\mathrm{H} 3$ & $\begin{array}{l}\text { - Portfolio entrepreneurs } \\
\text { - 'This was an opportunity, definitely spotted opportunity' (60-66) }\end{array}$ \\
\hline H5 & $\begin{array}{l}\text { - The city did not have a hotel, the entrepreneur saw a lifetime } \\
\text { opportunity (28-30) } \\
\text { - No fear for investment, confident he will succeed (66-70) }\end{array}$ \\
\hline H6 & $\begin{array}{l}\text { - Portfolio entrepreneur } \\
\text { - Emphasize intuition as crucial in decision to run a hotel. 'It was a sort } \\
\text { of intuition, even right now I am thinking why I did this..I had money } \\
\text { and established businesses (206-307) } \\
\text { - Lack of accommodation capacities in the city made the decision even } \\
\text { stronger ('an opportunity to make a good profit' - 58-59) }\end{array}$ \\
\hline H15 & $\begin{array}{l}\text { - Returning migrant } \\
\text { - 'If I thought that I won't make money with this business I would not } \\
\text { invest in it.' (49-50) }\end{array}$ \\
\hline $\mathrm{H} 21$ & $\begin{array}{l}\text { - Portfolio entrepreneurs in other sectors } \\
\text { - 'We saw an opportunity, and excellent opportunity to invest our } \\
\text { money' (58-59) }\end{array}$ \\
\hline \multirow[t]{3}{*}{ H29 } & $\begin{array}{l}\text { - Returning migrant (owned a construction company) } \\
\text { - 'Contrary from construction sector, hotelier business brings better } \\
\text { results. Tourism is the most important sector for Croatian economy, it } \\
\text { cannot fail, we lack accommodation capacities, that was a great business } \\
\text { opportunity' }(60-62)\end{array}$ \\
\hline & Thematic code EM: LM (Entry motives/Lifestyle Motives) \\
\hline & Coded text segment, meaning interpretation and transcript reference \\
\hline $\mathrm{H} 2$ & $\begin{array}{l}\text { - Father's wish but would not be realised if the entrepreneur did not see } \\
\text { an opportunity to earn money (19-22) } \\
\text { - Rejected a well-paid job in the capital city (27-30) } \\
\text { - Combination of LM and SO }\end{array}$ \\
\hline $\mathrm{H} 4$ & $\begin{array}{l}\text { - An old desire. 'One day I will build a hotel at this place.'(27) } \\
\text { - Waiting for all pieces of the puzzle to fit together in order to take the } \\
\text { investment. (25-29) } \\
\text { - Combination of both (LM and SO) }\end{array}$ \\
\hline
\end{tabular}




\begin{tabular}{|l|l|}
\hline H16 & $\begin{array}{l}\text { - Unsatisfied with the job in state owned insurance company (24-30) } \\
\text { - The origin from the island was crucial in determining hotel's location } \\
\text { (24-30) } \\
\text { - A desire to earn something and leave it to the children (226-233) }\end{array}$ \\
\hline
\end{tabular}

In-depth analysis was achieved by examination of the data related to each sub-code within a specific master code. For instance, master code 'entry motivations' had two sub- codes: 'spotted opportunity' and 'lifestyle motives'. This stage of data analysis included detailed investigation and in-depth reading of matrix charts (Table 2) and research notes and where the analysis has revealed meaningful links, master codes were clustered into code families, or metacodes (Miles and Huberman, 1994). Miles and Huberman (1994, p.249) define clustering as 'a general name given to the process of inductively forming categories, and the iterative sorting of things...into those categories'. During the previous stage, the researcher was examining findings relating to each master code aiming to discover whether the evidence obtained related to that of other codes. Where the analysis showed meaningful links between the data, master codes would be clustered together, thus leading to the development of 'meta codes'. As a result, 7 master codes were subsequently synthesized to three meta-codes: 'environment for entrepreneurship'; 'life history and business orientation'; and 'economic conditions' (Figure 1), which also served as a basic structure to present findings. Development of meta-codes largely depends on the researchers' insights and embeddedness with the data, which makes it a fairly subjective process. However, this step in data analysis is framing the findings and enabling more focused interpretations. Therefore, it can be argued that framework analysis provides a comprehensive and transparent analysis without denying the necessary flexibility inherent in the use of qualitative data (Ritchie and Spencer, 1994).

Figure 1

Synthesis of master codes into meta codes.
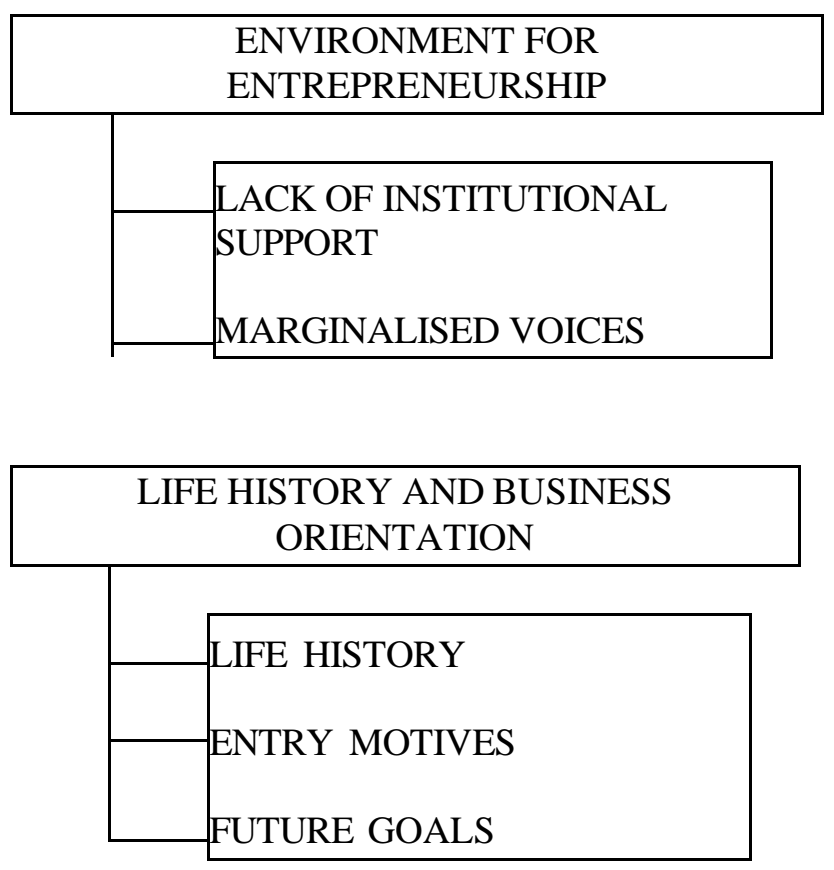


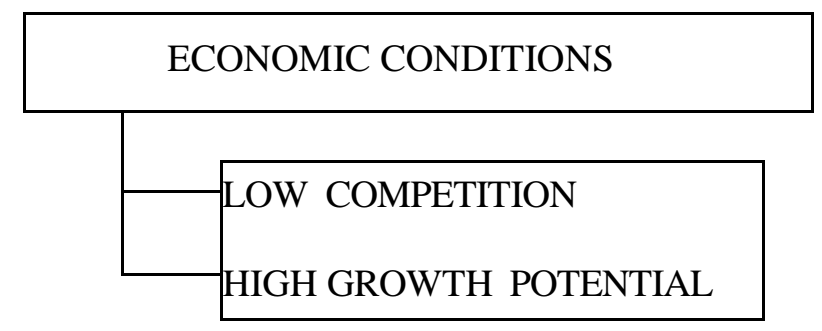

5. Findings

\subsection{Profile of the interviewed entrepreneurs}

Analysis revealed that the majority of participants are male between the ages of 40 and 49 years, holding a university degree, but mostly outside the fields of hospitality and tourism. A wide diversity of university backgrounds is evident, with degrees including economics, law, chemistry and art. Thirty-three businesses are registered as a sole proprietorship and four as a joint partnership. In terms of gender, only two women are sole proprietors and run the business independently. Ten participants are returning migrants. The length of time entrepreneurs had owned their businesses varied from 40 years (one owner) to just one year (one owner). The majority had owned their businesses from two to nine years, where the average time in a hotel business is 7 years. Most of the hotels have between 10-19 and 20-29 rooms. Interestingly, almost all participants have previous experience of owning and managing small business in a wide range of different sectors, such as, construction, finance and accounting and restaurants. A majority of participants (21) own another business besides a hotel, which classifies them as portfolio entrepreneurs. There are also 10 of the participants who are returning migrants, all except one being serial entrepreneurs, who had emigrated due to political or economic reasons and returned back when the communist system was abandoned in the 1990s (Table 3). 
Table 3

Profile of the interviewed entrepreneurs.

\begin{tabular}{|c|c|c|c|c|c|c|c|}
\hline Respondent & Sex & Age & Type of entrepreneur & $\begin{array}{l}\text { Owns/was owning } \\
\text { business in: }\end{array}$ & $\begin{array}{l}\text { Years in hotel } \\
\text { business }\end{array}$ & $\begin{array}{l}\text { Number } \\
\text { of rooms }\end{array}$ & Location \\
\hline H1 & $\begin{array}{l}\mathrm{M} \\
\mathrm{F}\end{array}$ & $40 \mathrm{~s}$ & Portfolio & Finance and Accounting & 2 & 7 & City Centre \\
\hline $\mathrm{H} 2$ & M & $20 \mathrm{~s}$ & Novice & / & 1 & 11 & Seaside \\
\hline H3 & $\begin{array}{l}\mathrm{M} \\
\mathrm{F}\end{array}$ & $30 \mathrm{~s}$ & Portfolio & Real estate & 5 & 28 & City Centre \\
\hline H4 & M & $40 \mathrm{~s}$ & Portfolio & $\begin{array}{l}\text { Finance and Accounting } \\
\text { Restaurants }\end{array}$ & 3 & 23 & City Centre \\
\hline H5 & M & $60 \mathrm{~s}$ & Portfolio & Restaurants & 40 & 36 & Inland \\
\hline H6 & M & $40 \mathrm{~s}$ & Portfolio & $\begin{array}{l}\text { Transport } \\
\text { Solicitor }\end{array}$ & 4 & 12 & City Centre \\
\hline $\mathrm{H} 7$ & M & $40 \mathrm{~s}$ & Portfolio & $\begin{array}{l}\text { Retail } \\
\text { Bakery }\end{array}$ & 4 & 24 & City Centre \\
\hline H8 & M & $50 \mathrm{~s}$ & $\begin{array}{l}\text { Serial } \\
\text { (Returning migrant) }\end{array}$ & Restaurant & 3 & 12 & Seaside \\
\hline H9 & M & $30 \mathrm{~s}$ & Portfolio & $\begin{array}{l}\text { Retail } \\
\text { Restaurant }\end{array}$ & 7 & 34 & Seaside \\
\hline H10 & M & $60 \mathrm{~s}$ & Portfolio & $\begin{array}{l}\text { Construction } \\
\text { Real estate }\end{array}$ & 7 & 33 & City Centre \\
\hline H11 & M & $40 \mathrm{~s}$ & Portfolio & Energy & 5 & 18 & Island \\
\hline H12 & $\begin{array}{l}M \\
F\end{array}$ & $40 \mathrm{~s}$ & $\begin{array}{l}\text { Serial } \\
\text { (Returning migrant) }\end{array}$ & Travel agency & 5 & 22 & Island \\
\hline H13 & $\mathrm{F}$ & $50 \mathrm{~s}$ & Portfolio & Art studio & 4 & 13 & Island \\
\hline H14 & M & $60 \mathrm{~s}$ & Serial & Construction & 8 & 30 & Island \\
\hline H15 & M & $60 \mathrm{~s}$ & $\begin{array}{l}\text { Serial } \\
\text { (Returning migrant) }\end{array}$ & Restaurant & 7 & 24 & Inland \\
\hline H16 & $\mathrm{F}$ & $50 \mathrm{~s}$ & Portfolio & $\begin{array}{l}\text { Transport } \\
\text { Leasing (beach } \\
\text { equipment) }\end{array}$ & 4 & 6 & Island \\
\hline
\end{tabular}




\begin{tabular}{|c|c|c|c|c|c|c|c|}
\hline H17 & $\mathrm{M}$ & $40 \mathrm{~s}$ & $\begin{array}{l}\text { Serial } \\
\text { (Returning migrant) }\end{array}$ & Restaurant & 4 & 36 & Seaside \\
\hline H18 & $\mathrm{M}$ & $40 \mathrm{~s}$ & Portfolio & Finance & 18 & 39 & Seaside \\
\hline H19 & $\mathrm{M}$ & $50 \mathrm{~s}$ & $\begin{array}{l}\text { Serial } \\
\text { (Returning migrant) }\end{array}$ & Restaurant & 3 & 12 & City Centre \\
\hline $\mathrm{H} 20$ & $\mathrm{M}$ & $40 \mathrm{~s}$ & Novice & I & 3 & 32 & Seaside \\
\hline $\mathrm{H} 21$ & $\mathrm{M}$ & $60 \mathrm{~s}$ & Portfolio & $\begin{array}{l}\text { Manufacturing } \\
\text { Trade }\end{array}$ & 4 & 21 & City Centre \\
\hline $\mathrm{H} 22$ & $\mathrm{M}$ & $40 \mathrm{~s}$ & Portfolio & Trade & 3 & 16 & Seaside \\
\hline $\mathrm{H} 23$ & $\mathrm{M}$ & $50 \mathrm{~s}$ & Portfolio & $\begin{array}{l}\text { Restaurant } \\
\text { B\&B }\end{array}$ & 14 & 15 & Seaside \\
\hline $\mathrm{H} 24$ & $\mathrm{M}$ & $60 \mathrm{~s}$ & $\begin{array}{l}\text { Serial } \\
\text { (Returning migrant) }\end{array}$ & Restaurant & 7 & 13 & Seaside \\
\hline $\mathrm{H} 25$ & $\mathrm{M}$ & $30 \mathrm{~s}$ & Portfolio & $\begin{array}{l}\text { Real estate } \\
\text { Restaurant }\end{array}$ & 3 & 12 & City Centre \\
\hline $\mathrm{H} 26$ & $\mathrm{M}$ & $50 \mathrm{~s}$ & Portfolio & $\begin{array}{l}\text { Trade } \\
\text { Restaurants }\end{array}$ & 9 & 14 & Seaside \\
\hline $\mathrm{H} 27$ & $\begin{array}{l}\mathrm{M} \\
\mathrm{F}\end{array}$ & $40 \mathrm{~s}$ & $\begin{array}{l}\text { Serial } \\
\text { (Returning migrant) }\end{array}$ & Construction & 7 & 29 & Inland \\
\hline $\mathrm{H} 28$ & $\mathrm{M}$ & $30 \mathrm{~s}$ & Portfolio & $\begin{array}{l}\text { Real estate } \\
\text { Restaurant } \\
\text { Travel agency }\end{array}$ & 8 & 25 & City Centre \\
\hline $\mathrm{H} 29$ & $\mathrm{M}$ & $50 \mathrm{~s}$ & $\begin{array}{l}\text { Serial } \\
\text { (Returning migrant) }\end{array}$ & Construction & 13 & 23 & Seaside \\
\hline H30 & $\mathrm{M}$ & $50 \mathrm{~s}$ & Serial & $\begin{array}{l}\text { Restaurant } \\
\text { B\&B }\end{array}$ & 5 & 33 & City Centre \\
\hline H31 & $\mathrm{M}$ & $40 \mathrm{~s}$ & Novice & I & 4 & 12 & Seaside \\
\hline H32 & $\mathrm{M}$ & $40 \mathrm{~s}$ & $\begin{array}{l}\text { Portfolio } \\
\text { (Returning migrant) }\end{array}$ & Bakery & 7 & 26 & Seaside \\
\hline H33 & $\mathrm{M}$ & $50 \mathrm{~s}$ & Portfolio & Finance and accounting & 6 & 24 & City Centre \\
\hline H34 & $\mathrm{M}$ & $40 \mathrm{~s}$ & $\begin{array}{l}\text { Serial } \\
\text { (Returning migrant) }\end{array}$ & $\begin{array}{l}\text { Trade } \\
\text { Agriculture }\end{array}$ & 8 & 23 & Island \\
\hline H35 & $\mathrm{M}$ & $40 \mathrm{~s}$ & Novice & I & 2 & 12 & Island \\
\hline H36 & $\mathrm{M}$ & $30 \mathrm{~s}$ & Novice & I & 2 & 15 & City Centre \\
\hline H37 & $\mathrm{M}$ & $50 \mathrm{~s}$ & Portfolio & Real estate & 5 & 32 & Inland \\
\hline
\end{tabular}




\subsection{The impact of economic restructuring}

Only one respondent (H16), based on an island, reveals a purely lifestyle-entry motive. This motive can be classified as dissatisfaction with a job in a state-owned company combined with a desire to move to the island and leave some inheritance to the children. All other participants reported that their decision to open a small hotel was exclusively based on an identified opportunity and desire to earn a profit. Even those interviewees who had experience in the sector stated that this previous work history has not influenced their decision, but that the idea came 'naturally' (H17). The identified opportunity was perceived in favorable market trends, where some interviewees saw an opportunity to expand their existing business portfolio by investment in a hotel:

I saw that tourists are coming back, the government started to take tourism seriously.. it was a sort of intuition. I did not need a new business, I have enough money and established companies, but it really looked as an opportunity which cannot be missed. (H1O)

I decided to invest in a hotel not because I knew how to do it, how a hotel works, but only because I had money and I saw a good opportunity. I do not have experience but my employees and the main manager are well experienced and run a good business. (H31)

The interviewees identified favorable market trends as the lack of accommodation capacity in the analyzed county and an increased tourist demand for small hotels. This empty niche market segment is created by the process of market reforms which were slowed down and partially stalled because of the civil war in Croatia and postponed privatization process in the hospitality and tourism (H\&T) sector. Participants consider their decision to start a hotel business as 'normal' and 'that every 'real' entrepreneur would do it' (H23).

The majority of interviewees reported they had private funds to finance their investment. Nevertheless, 18 participants combined private sources with a loan to start-up a business where the share of borrowed funds was on average 30\%. Probing further they explain this decision as a favorable opportunity:

The interest rate was so cheap and favorable, it would be ridiculous to miss it.

This was a simply one good opportunity to exploit. (H3)

Rejection of the lifestyle concept has distinct effects on entrepreneurial behavior, such as business growth. All but five participants out of 37 reported that they had already undertaken actions which would facilitate growth: 10 of them had already grown; 17 are in a process of growth, whereas five of them have already grown, thus are involved in a second growth. All participants have increased their number of employees as well. The participants who did not wish to grow are a lifestyle entrepreneur and four returning migrants. There was no significant difference in growth orientation and the size of a hotel or the length of time involved in business. For instance, the respondent (H5) who has been running a hotel for 40 years expanded his hotel capacities once with an additional 10 rooms (from 26 to 36) and currently is developing 'a heritage village'. On the other hand, a respondent who started with a smaller hotel (seven rooms) was involved in construction of a new hotel (H1).

Reported categories of growth include: hotel expansion in terms of number of rooms; investment in a new hotel; augmentation in quality (such as construction of swimming pools and meeting rooms); increase in number of employees; and investment in other businesses 
outside the H\&T sector. The interviewees' economic mind-set is further illustrated when discussing the rationale behind business growth:

I am currently involved in a hotel expansion, which can bring me only higher profit. You see, I will increase the number of rooms for thirty percent and I will only need one more housemaid and a waiter, in terms of variable costs, that's it. In terms of profit, I will be able to concentrate on large groups, which is the most profitable for me. (H17)

There is no entrepreneur in this world who started a business and does not think about expanding his job. I mean, if you do not think in this way something is wrong with you, you are not a true entrepreneur. (H6)

\subsection{Fighting the historical legacies and institutional conditions}

During the period of socialism in Croatia, private initiative was formally restricted with slightly flexible rules concerning the H\&T sector. Despite the formal possibility to establish a small enterprise in the sector, entrepreneurial endeavors were constantly hindered. Namely, those respondents whose families (eight) decided to start small businesses during this time did not have any legal security and were facing significant difficulties that will be illustrated with the following example:

My parents opened a restaurant in 1965, they also had one before the Second World War, but that restaurant was taken by the authorities...And again in 1970s they opened a small motel. We could do that, the law stated that you can open a small motel and a restaurant. But because of the new, property origin law, which was a legal document to rob entrepreneurs, authorities again took everything.. So twice my parents lost everything they had. (H28)

This experience reflects the actual treatment of entrepreneurship and entrepreneurs during the socialist period, which although allowed in certain sectors, was portrayed by the Communist party as a rather negative and dangerous western practice. Therefore, people did not want to be associated with entrepreneurship. Entrepreneurs explained that being an entrepreneur during the socialist period literally meant that 'you are an enemy of your country' (H5).

The development of entrepreneurship after the collapse of socialism has been one of the major preoccupations for the Croatian government. Regardless of this, all entrepreneurs interviewed in this study emphasized the difficulties in the institutional environment which have affected their businesses. Two main themes are identified: lack of institutional support and marginalized voices. A vast number of participants (21) experienced significant administrative start-up barriers and they reported that they needed from four to ten years to obtain a building permit. Also, participants could neither register ownership of assets nor even dispose of the private asset:

We own this house since the $17^{\text {th }}$ century. And yet, I cannot register myself as the owner, although I have all the documents which the government officials have asked me to provide. I cannot do anything with it, as I cannot sort out the ownership of the property for the last 10 years! (H13) 
I could not ask for a construction permit for a hotel because they changed the purpose of my land from 'construction/developmental zone' to 'residential zone'. So they told me (mimicking voice) "If you think to get the license for your hotel, ask the authorities to grant you the license on the residential purposes." I had to pretend that my hotel will be a house for living! That is a total discrepancy in our legislation which prevent all of us [entrepreneurs] to do any serious job! (H5)

The position of entrepreneurs within Croatian society is a somewhat unexpected finding, as for two decades the country has tried to establish itself as an entrepreneurial economy. Participants experienced a variety of negative attitudes towards entrepreneurs where the most striking of these is the popular portrayal of entrepreneurs as thieves and tycoons, reflecting the still-dominant influence of Croatia's transition period:

You have a situation that people compare everyone who works hard, and we work really hard, with 'tycoons'. That is equal to some suspicion towards you, like who is standing behind me and this is how the environment created us a problem. People do not realize that those who stole the country do not work, they stole and sold everything they could. (H26)

That is unbelievable, all my friends think I lost my mind because I have my own business...I do not know, maybe people still want the safety of socially-owned companies and they are not sure what entrepreneurs are doing, they think we are sort of dodgers. And our country did not do anything to improve our status, actually it only made our position worse with numerous intrigues. (H32)

Interestingly, when asked how they would define themselves, the participants appeared to strive to reveal those attributes which prove the opposite to the prejudices that have emerged and reveal 'a true' picture of the entrepreneurs:

The climate in the society around the 1990s towards entrepreneurs was hostile. The entrepreneur was seen as a monster and it needs to be destroyed. Today things are getting better but still Croatian society does not appreciate entrepreneurship as it is done in the States for instance. Entrepreneurship is all about dedication, hard work, sacrifice and the persistence to start-up and grow your business. (H18)

When you look at the national level, there are so many available support programs for entrepreneurship. But we cannot change, actually maybe we did not even try to, the public perception of entrepreneurs. But who would blame them when the only thing you can read about entrepreneurs from the newspapers are bombastic headlines, such as 'Entrepreneur X accused of...' or 'Entrepreneur Y proved to be guilty...' It seems to me that the words 'tycoon' and 'entrepreneur' are used interchangeably. Maybe 20 years is still nothing for people to forget what has happened during the privatization process. (H27)

Even though this feature of institutional environment had the potential to hinder entrepreneurial activity, it stimulated entrepreneurs to present a heroic picture of their role and to devise creative ways to overcome these institutional obstacles. For instance, some of the participants opted to work illegally until they sorted out all permits and even registered their hotel as rooms to let, just to start working. On the other hand, entrepreneurs have experienced 
difficulties in getting short-term bank loans to finance hotel equipment or any of their identified growth strategies. In order to avoid banks and to find additional sources, a significant number of respondents used 'trade credit'. In this case it is a deal with suppliers for prolonged payments, without imposed interests:

\begin{abstract}
After some time you start avoiding banks.. I think banks' treatment of entrepreneurs has created a critical mass of people across the sectors. So suppliers get me the furniture for instance, wait on me for a month and I pay them. It is good for both as I can use that money to cover operational expenses and suppliers are finally selling and making some money. (H7)
\end{abstract}

\title{
6. Discussion
}

This study has analyzed how hotel entrepreneurs articulate and respond to the complex changes in the socio-economic environment of a former socialist economy. The findings demonstrate that the economic conditions - low level of competition and the high growth potential of tourism, has opened up the doors for hotel entrepreneurs in Croatia. Institutional gaps also created empty niche markets across various sectors which helped to draw the participants of this study into portfolio entrepreneurship. Hence, it can be argued that the hotel business does not represent a buffer against the volatility of the transition markets (Estrin et al. 2006). Rather, a partially reformed economy offered lucrative unfilled niche markets, which entrepreneurs spotted and responded to. These gaps have also affected the behavioral characteristics of entrepreneurs and perhaps even forced them to be more risk-taking, creative, proactive and more market-driven in their outlook, contrary to the stereotype of lifestyle entrepreneurs (Morrison et al. 2001).

Despite its complexity and unpredictability, environmental turbulence seems to be a major catalyst for entrepreneurial activities to happen. In Croatia, a partially reformed economy offered lucrative unfilled niche markets which entrepreneurs spotted and responded to (Johnson et al. 2002). They engaged in entrepreneurial activities during the early years of the market reforms, investing in different sectors, such as retail and trade (Table $z 3$ ). The starting point was a heavily distorted economy with unfilled markets. Participants who were able to overcome institutional barriers to do business and produce and sell goods and services were profitable. During the later years of transition interviewed entrepreneurs moved into the hospitality sector which was perceived as the sector which offered the most lucrative opportunities at that point. As demonstrated in the current study, the tourism sector in Croatia needed a whole decade to recover from the transitional changes and the civil war. Once the entrepreneurs spotted an increase in tourist arrivals and insufficient accommodation supply they responded to another lucrative unfilled market segment.

On the other hand, regulatory burdens and inconsistencies in the legal framework affected a number of entrepreneurs and have caused delays in starting up businesses. The findings demonstrate that entrepreneurs confront problems associated with a lack of legitimacy, as public acceptance of entrepreneurs appears to be low. The legitimacy flows from the cultural support for a new venture, which in the Croatian case is still minimal. This was also observed across the CEE economies (Ahlstrom and Bruton, 2010). Smallbone and Welter (2012, p. 217) argued that government normative mechanisms should assist in creating legitimacy, as the way that government deals with entrepreneurs influences 'the extent to which involvement in entrepreneurship is an acceptable form of behaviour within the population as a whole, as does the behaviour of entrepreneurs themselves'. Chilosi (2001) added that in countries where the level of institutional trust is low, such as in the reported case, the distinction between legitimate 
and illegitimate entrepreneurship may become blurred. There is evidence among the CEE countries that in some cases entrepreneurs in order to attempt to establish legitimacy, may result in avoidance strategies, such as tax evasion (Pissarides, 1998) or developing a set of personal networks such as blat in Russia to access goods and services by exchanging gifts and favours outside the state's control (Manolova et al. 2008). However, it can be argued that the emergence of entrepreneurs in such an ambiguous environment, where there is no security of property rights or a developed institutional framework, is rather remarkable. For instance, Smallbone and Welter (2001, p. 252) argue that 'Russian economy of favors have played a major role in transforming entrepreneurial activities that existed during the socialist period into capitalist entrepreneurship during transition'. Similarly, Webb et al. (2009, p. 28) argue that 'weak enforcement of formal laws and regulations enhances the relationship between opportunity recognition and exploitation in the informal economy' and consider such ventures as legitimate. Interviewees also were proactive in responding to the institutional barriers by developing a set of 'coping' strategies. For instance, 'trade credit' is a replacement for a short-term bank loan and it represents a form of financial bootstrapping (Smallbone and Welter, 2001). On the other hand, illegal activity is sometimes felt to be the only way to do business and it almost becomes a necessity where there is no security of property rights.

Due to the analyzed ideological and institutional barriers it is less likely that someone would enroll in entrepreneurial activity solely for lifestyle-related motives. This entrepreneurial behavior was particularly evident in growth strategies undertaken which included not only expansion of the existing businesses, but investment in other unfilled sectors. Therefore, the entrepreneurs who participated in this research do not measure business success 'in terms of a continuing ability to perpetuate their chosen lifestyle' (Dewhurst and Horobin, 1998, p. 30). This finding provides further evidence that institutional deficiencies may actually stimulate market orientation and demand driven behavior, even in circumstances where extant research would predict a lifestyle orientation.

In addition, within transition settings, entrepreneurs have to prove they have positive intentions and demonstrate their importance for economic development. They are not perceived by the public as heroes, agents of change or warriors (Nicholson and Anderson, 2005). Instead, a broad cultural acceptance of entrepreneurs and enterprising behavior is missing. Our findings demonstrate that even after twenty years of market reforms, decades of socialist influence have ingrained values that are strongly opposed to the pursuit of entrepreneurship.

\section{Conclusions and implications}

The findings of this study have important implications for the hospitality entrepreneurship literature. The entrepreneurial behavior of SHTF has often been described as 'lifestyle' (Ioannides and Petersen, 2003). In contrast, this study demonstrates through the complex setting of a former socialist economy that the lifestyle concept takes on a very different meaning. In this context, entrepreneurial autonomy is not related to the autonomy of 'being my own boss' (Getz and Petersen, 2005, p. 230) but it is related to actual freedom from the communist regime and the possibility of establishing one's own enterprise. In a turbulent transition environment, entrepreneurship appears as a means to exploit lucrative niche markets and it does not leave room for lifestyle-related motives, as defined in a Western frame of reference. Therefore, our findings do not oppose the lifestyle concept. They rather suggest that the specific socio-economic context of the analyzed entrepreneurs, and not the entrepreneurs alone, sets the conditions by which lifestyle-related motivations can exist or not. In this case, the lifestyle concept also embraces dimensions outside the entrepreneurial agency, such as the historical legacies, institutional framework and position of the entrepreneurs in the society. 
We were able to arrive at this observation by contextualising this study spatially, institutionally and temporally. A contextualised approach in entrepreneurship research has the capacity to recognise and encompass not only formal and informal institutional features but all those environmental and social factors that affect entrepreneurship. For instance, even though an underdeveloped legal framework is seen as a major inhibitor of entrepreneurship (Johnson et al. 2002), in this Croatian case it acted as a barrier in business operations, but not as a constraint to engage with entrepreneurship. Similarly, low public acceptance of entrepreneurs additionally pushed them to be more profit than lifestyle driven in their behavior. However, mainstream entrepreneurship literature and H\&T entrepreneurship studies directly assume a strong entrepreneurial culture despite the fact that these attitudes towards entrepreneurship may change in time and some societies may not even consider entrepreneurial ventures as legitimate (Ogbor, 2000). This foregoing insight points to the importance of recognizing the wider context of entrepreneurship research. Jennings et al. (2005, p. 147) argue that mainstream entrepreneurship research has often acted as though investigated social structures are 'natural and unchallengeable facts.' Recognition of the context in entrepreneurship research is in contrast to dominant individualistic explanations of entrepreneurship, as inclusion of transition economies requires that perceptions of entrepreneurship and entrepreneurs are developed by the ongoing structure of social relations. This study has demonstrated that inclusion of transitional economies into the mainstream reasoning offers the potential to expand our theoretical understanding of entrepreneurship, and shows how culturally bounded entrepreneurial behavior is.

This in turn has two consequences. Firstly, H\&T entrepreneurship research would benefit from more contextualized theories which allow us to 'understand and analyze the effects multiple contexts have on entrepreneurship and the ways entrepreneurship influences context, from a dynamic perspective' (Welter, 2011, p. 175). Some of the assumptions in the literature should be revisited. For instance, the assumptions of lifestyle orientation and non-growth of SHTF may not be universal, as demonstrated in this case. With respect to methodological approaches, Blackburn and Kovalainen (2009) and Thomas et al. (2011) argue that small firms in transitional economies present novel research areas and as such call for primary research across different settings. Eisenhardt (1989, p. 548) demonstrates that use of the case study is particularly appropriate since when 'little is known about a phenomenon, current perspectives seem inadequate because they have little empirical substantiation, or they conflict with each other or common sense.'

Hence, it would be necessary to analyze how identified contextual variables, such as perception of entrepreneurs differ across the settings and to what degree they shape entrepreneurial goals, behavior and their actions. After this is achieved, it will be possible to test identified variables and to investigate for alternative explanations, such as the possible effects of the tourism area lifecycle (Russell and Faulkner, 2004). Those variables that have the highest explanatory power and are generalizable in other contexts can be included in a broader theoretical framework. Hopefully, once this is achieved, the field of SHTF will move away from the current state of development described by Thomas et al. (2011) as: 'largely under theorized and researched in isolation of their wider context' (p. 964)...'developed around assumptions which are not borne out by the evidence and with a limited impact to mainstream studies of small businesses' (p. 972).

Finally, our study indicates three important areas for future research. First, almost all participants in this study were portfolio entrepreneurs. Portfolio orientation is a rather unexpected finding, particularly in the tourism sector where entrepreneurship is largely associated with the notion of lifestyle motives (Ioannides and Petersen, 2003). However, Estrin et al. (2006, p. 716) argue that within transition economies portfolio entrepreneurship 'is another way for businesses to hedge against the volatility of markets in transition.' This implies 
that portfolio orientation among small entrepreneurs in transitional settings is not uncommon, although the reasons for its presence may be different. For instance, portfolio orientation may be adopted as one of the strategies to adopt or to evolve in rapidly changing institutional environments and thus calls for further investigation. A second related point is that future studies could investigate in more depth different types of entrepreneur and their consequent goals. An increasing number of studies is suggesting that lifestyle orientation does not always defy the logic of economic rationality and business growth (Ahmad, 2015). Thirdly, the nature of tourism destination development may have an impact on entrepreneurial motivation (Russell and Faulkner, 2004; Weiermair et al. 2007) and future studies could investigate the link between the stages in destination development, entrepreneurial motivation and their goals.

\section{References}

Ahmad, S., 2015. Entrepreneurship in the small and medium-sized hotel sector. Current Issues in Tourism, 18(4), 328-349.

Ahmad, S., Jabeen, F. and Khan, M. 2014. Entrepreneurs choice in business venture: Motivations for choosing home-stay accommodation businesses in Peninsular Malaysia. International Journal of Hospitality Management, 36, 31-40.

Aidis, R., 2005. Entrepreneurship in transition countries: a review. Working Paper No. 61. Centre for the Study of Economic and Social Change in Europe, UCL.

Aidis, R., Estrin, S., Mickiewicz, T., 2008. Institutions and entrepreneurship development in Russia: a comparative perspective. Journal of Business Venturing, 23(6), 653-672.

Ahlstrom, D., Bruton, G. D. 2010. Rapid institutional shifts and the co-evolution of entrepreneurial firms in transition economies. Entrepreneurship Theory and Practice, 34(3), 531-554.

Andersson, T., Carlsen, J., Getz, D. 2002. Family busi ness goals in the tourism and hospitality sector: case studies and cross-case analysis from Australia, Canada, and Sweden. Family Business Review, 15(2), 89-106.

Andriotis, K., 2002. Scale of hospitality firms and local economic development: Evidence from Crete. Tourism Management, 23, 333-341.

Ateljevic, I., Doorne, S., 2000. Staying with the fence: lifestyle entrepreneurs in tourism. Journal of Sustainable Tourism, 8(5), 378-392.

Ateljevic, I., Doorne, S., 2003. Unpacking the local: a cultural analysis of tourism entrepreneurship in Murter, Croatia. Tourism Geographies, 5(2), 123-150.

Ateljevic, J., 2007. Small tourism firms and management practice in New Zealand: the Centre stage macro region. Tourism Management, 28(1), 307-316.

Ateljevic, J., 2009. Tourism entrepreneurship and regional development: example from New Zealand. International Journal of Entrepreneurial Behaviour and Research, 15(3), 282308.

Banki, M., Ismail, H. 2015. Understanding the characteristics of family owned tourism micro businesses in mountain destinations in developing countries: evidence from Nigeria. Tourism Management Perspectives, 13, 18-32.

Blackburn, R., Kovalainen, A., 2009. Researching small firms and entrepreneurship: past, present and future. International Journal of Management Reviews, 11(2), 127-148.

Bruton, G. D., Ahlstrom, D., Li, H. L. 2010. Institutional theory and entrepreneurship: where are we now and where do we need to move in the future? Entrepreneurship Theory and Practice, 34(3), 421-440.

Chen, S., Elston, J. 2013. Entrepreneurial motives and characteristics: an analysis of small restaurant owners. International Journal of Hospitality Management, 35, 294-305. 
Chilosi, A., 2001. Entrepreneurship and transition. MOCT-MOST Economic Policy in Transitional Economies, 11(4), 327-357.

Davidsson, P., Wiklund, J. 1997. Values, beliefs and regional variations in new firm formation rates. Journal of Economic Psychology, 18, 179-199.

Dickson, P., Weaver, K., 2008. The role of the institutional environment in determining firm orientation towards entrepreneurial behaviour. International Entrepreneurship and Management Journal, 4(4), 467-483.

Dewhurst, P., Horobin, H., 1998. Small business owners. In R. Thomas (Ed.), The management of small tourism and hospitality firms (pp. 19-39). London: Cassell.

Eisenhardt, K., 1989. Building theories from case study research. Academy of Management Review, 14(4), 532-550.

Estrin, S., Meyer, K., Bytchkova, M., 2006. Entrepreneurship in transition economies. In M. Casson, B. Yeung, A. Basu, and N. Wadeson (Eds.), The Oxford Handbook of Entrepreneurship (pp. 693-725). Oxford: Oxford University Press.

Eurofound, 2015. Youth entrepreneurship in Europe: Values, attitudes, policies. Luxembourg: Publications Office of the European Union.

Gartner, W., 2004. Factors affecting small firms in tourism: a Ghanaian perspective. In R. Thomas (Ed.), Small firms in tourism: international perspectives (pp. 35-52). Oxford: Elsevier.

Getz, D., Petersen, T., 2005. Growth and profit oriented entrepreneurship among family business owners in the tourism and hospitality industry. International Journal of Hospitality Management, 24(2), 219-242.

Glancey, K., Pettigrew, M., 1997. Entrepreneurship in the small hotel sector. International Journal of Contemporary Hospitality Management, 9(1), 21-24.

Hall, M., Rusher, K., 2004. Risky lifestyles? Entrepreneurial characteristics of the New Zealand Bed and Breakfast sector. In R. Thomas (Ed.), Small firms in tourism: international perspectives (pp. 83-97). Oxford: Elsevier.

Hallak, R., Brown, G., Lindsay, N., 2012. The place identity-performance relationship among tourism entrepreneurs: a structural equation modelling analysis. Tourism Management, 33(1), 143-154.

Hayton, J.C., George, G., Zahra, S. 2002. National culture and entrepreneurship: A review of behavioural research. Entrepreneurship Theory and Practice, 26(4), 3352.

Ioannides, D., Petersen, T., 2003. Tourism 'non-entrepreneurship' in peripheral destinations: a case study of small and medium tourism enterprises on Bornholm, Denmark. Tourism Geographies, 5(4), 408-435.

Ireland, D., Tihanyi, L., Webb, J., 2008. A tale of two politico-economic systems: Implications for entrepreneurship in Central and Eastern Europe. Entrepreneurship Theory and Practice, 32(1), 107-130.

Jaafar, M., Abdul-Aziz, A., Maideen, S., Mohd, S., 2011. Entrepreneurship in the tourism industry: issues in developing countries. International Journal of Hospitality Management, 30(4), 827-835.

Jennings, P., Perren, L., Carter, S., 2005. Guest editors' introduction: alternative perspectives on entrepreneurship research. Entrepreneurship Theory and Practice, 29(2), 145-152.

Johnson, S., McMillan, J., Woodruff, C. 2002. Property rights and finance. The American Economic Review, 92(5), 1335-1356.

Keen, D. 2004. The interaction of community and small tourism business in rural New Zealand. In R. Thomas (Ed.), Small firms in tourism: international perspectives (pp. 139-154). Oxford, Elsevier.

Kobasic, A., 1987. Turizam u Jugoslaviji: Razvoj, stanje, perspektive. Zagreb: Informator. 
Kolodko, G., 2000. Transition to a market and entrepreneurship: The systemic factors and policy options. Communist and Post-Communist Studies 33(2), 271-93.

Komppula, R., 2004. Success and growth in rural tourism micro-businesses in Finland: Financial or lifestyle objectives? In R. Thomas (Ed.), Small firms in tourism: international perspectives (pp. 115-138). Oxford, Elsevier

Kovac, B., 1990. Političko-ekonomska uloga poduzetništva. In D. Njavro and V. Franičević (Eds.), Poduzetništvo. (pp. 69-93). Zagreb: Privredni Vjesnik.

Lashley, C., Rowson, B., 2010. Lifestyle businesses: insights into Blackpool's hotel sector. International Journal of Hospitality Management, 29(3), 511-519.

Manolova, T., Eunni, R., Gyoshev, B., 2008. Institutional environments for entrepreneurship: evidence from emerging economies in Eastern Europe. Entrepreneurship Theory and Practice, 32(1), 203-218.

Miles, M., Huberman, M., 1994. Qualitative data analysis. Thousands Oaks, CA: Sage.

MINT. 2005. Obiteljski Mali Hoteli (Small Family Hotels). Zagreb: MINT.

Morrison, A., Baum, T., Andrew, R., 2001. The lifestyle economics of small tourism businesses. Journal of Travel and Tourism Research, 1(1-2), 16-25.

Morrison, A., Teixeira, R., 2004. Small business performance: a tourism sector focus. Journal of Small Business and Enterprise Development, 11(2), 166-173.

Mottiar, Z., 2007. Lifestyle entrepreneurs and spheres of inter-firm relations. Entrepreneurship and Innovation, 8(1), 67-74.

Nicholson, L., Anderson, A., 2005. News and nuances of the entrepreneurial myth and metaphor: linguistic games in entrepreneurial sense-making and sense-giving. Entrepreneurship Theory and Practice, 29(2), 153-172.

North, D. C. 1990. Institutions, institutional change and economic performance. Cambridge: Cambridge University Press.

Ogbor, J. 2000. Mythicizing and reification in entrepreneurial discourse: Ideology-critique of entrepreneurial studies, Journal of Management Studies, 37(5), 605-635.

Page, S., Forer, P., Lawton, G., 1999. Small business development and tourism: Terra incognita? Tourism Management, 20(4), 435-459.

Paz, O., 1992. Translation: literature and letters. In R. Schulte and J. Biguenet (Eds.), Theories of Translation (pp. 152-162). Chicago: The University of Chicago Press.

Pissarides, F. 1998. Is lack of funds the main obstacle to growth? European Bank for Reconstruction and Development, Working Paper No 33.

Ramos-Rodríguez, A.R., Medina-Garrido, J.A., Ruiz-Navarro, J.R., 2012. Determinants of hotel and restaurant entrepreneurship: a study using GEM data. International Journal of Hospitality Management, 31, 579-587.

Ritchie, J., Spencer, L., 1994. Qualitative data analysis for applied policy research. In A. Bryman and R. Burgess (Eds.), Analyzing qualitative data (pp. 173-194). London: Routledge.

Russell, R., Faulkner, B., 2004. Entrepreneurship, chaos and the tourism area lifecycle. Annals of Tourism Research, 31(3), 556-579.

Saprunova, V., 2004. Small business in the tourism and hospitality industry of Russia. In R. Thomas and M. Augustyn (Eds.), Tourism in the new Europe: perspectives on SME policies and practices (pp. 215-226). Oxford: Elsevier.

Scase, R., 2000. Entrepreneurship and proprietorship in transition: policy implications for the small-and medium-size enterprise sector. Helsinki: United Nations University World Institute for Development Economic Research.

Sekulic, D., Sporer, Z., 2000. Political transformation and elite transformation in Croatia. European Sociological Review, 18(1), 85-100.

Shane, S. 2003. A general theory of entrepreneurship. The individual-opportunity nexus. 
Cheltenhalm: Edgar Elgar.

Shaw, G., Williams, A., 1987. Firm formation and operating characteristics in the Cornish tourist industry-the case of Looe. Tourism Management, 8(4), 344-348.

Shaw, G., Williams, A., 1998. Entrepreneurship, small business, culture and tourism development. In D. Ioannides and K. Debbage (Eds.), The economic geography of the tourist industry: a supply-side analysis (pp. 235-255). London: Routledge.

Shaw, G., Williams, A., 2004. From lifestyle consumption to lifestyle production: Changing patterns of tourism entrepreneurship. In R. Thomas (Ed.), Small firms in tourism: international perspectives (pp. 99-113). Oxford: Elsevier.

Smallbone, D., Welter, F., 2001. The distinctiveness of entrepreneurship in transition economies. Small Business Economics, 16(4), 249-262.

Smallbone, D., Welter, F., Voytovich, A., Egorov, I., 2010. Government and entrepreneurship in transition economies: the case of small firms in business services in Ukraine. The Service Industries Journal, 30(5), 655-670.

Thomas, R., 2004. International perspectives on small firms in tourism: a synthesis. In R. Thomas (Ed.), Small firms in tourism: international perspectives (pp. 1-12). Oxford: Elsevier.

Thomas, R., Shaw, G., Page, S., 2011. Understanding small firms in tourism: a perspective on research trends and challenges. Tourism Management, 32(5), 963-976.

Tucker, H., 2010. Peasant-entrepreneurs: a longitudinal ethnography. Annals of Tourism Research, 37(4), 972-946.

Veciana, J. M., Urbano, D. 2008. The institutional approach to entrepreneurship research. Introduction. International Entrepreneurship and Management Journal, 4(4), 365-379.

Wanhill, S., 2000. Small and medium tourism enterprises. Annals of Tourism Research, 27(1), 132-147.

Webb, J. W., Tihanyi, L., Ireland, R. D., Sirmon, D. G. 2009. You say illegal, I say legitimate: Entrepreneurship in the informal economy. Academy of Management Review, 34(3), 492-510.

Weiermair, K., Peters, M., Schuckert, M., 2007. Destination development and the tourist lifecycle: implications for entrepreneurship in Alpine tourism. Tourism Recreation Research, 32(1), 83-93.

Welter, F., Smallbone, D., 2011. Institutional perspectives on entrepreneurial behaviour in challenging environments. Journal of Small Business Management, 49(1), 107-125.

Welter, F., 2011. Contextualizing entrepreneurship - conceptual challenges and ways forward. Entrepreneurship Theory and Practice, 35(1), 165-184.

Williams, A., Shaw, G., Greenwood, J., 1989. From tourist to tourism entrepreneur, from consumption to production: evidence from Cornwall, England. Environment and Planning, A, 21(12), 1639-1653.

Williams, A., Baláž, V., 2002. The Czech and Slovak republics: conceptual issues in the economic analysis of tourism transition. Tourism Management, 23(1), 37-45.

WTTC., 2014. Travel and Tourism Economic Impact: Croatia. London: WTTC.

Zapalska, A., Brozik, D., 2007. Managing family businesses in the tourism and hospitality industry: The transitional economy of Poland. Zbornik Radova Ekonomskog Fakulteta Rijeka, 25(1), 141-165.

Zhao, W., Getz, D., 2008. Characteristics and goals of rural family business owners in toruism and hospitality: a developing country perspective. Tourism Recreation Research, 33(3), 313-326. 